\title{
Time Allocation, Income and Gender Relation in the Household of Fishermen Who Have Employed Wives
}

\author{
Sri Fajar Ayu1, Meutia Nauly², Ratih Baiduri ${ }^{3}$
}

\author{
Departement of Agribusiness ${ }^{1}$ \\ Departement of Social Psychology2, \\ University of Sumatera Utara, Medan, Indonesia ${ }^{12}$ \\ Departement of Anthropology 3 \\ State University of Medan, Medan, Indonesia ${ }^{3}$ \\ srifajar.ayu@gmail.com¹,meutia@indieacademy.org22,ratihbaiduri215@gmail.com³
}

\begin{abstract}
This study is a mixed method that combines quantitative with qualitative analysis. There are several research objectives. First, to analyze the income and time allocation woman fishermans wife who works compared to her husband. Second, analyze the allocation of time housework and childcare in women fishermans wife who works compared to her husband. Third, analyzing gender relations (decision-making and access control) between husband and wife in the household of the working wife. The quantitative descriptive analysis shows that the total productive time of the wives works are 11 hours per day at the time range 16 hours a day (from at 6:00 AM to 22:00 $\mathrm{PM}$ ), while the husband is five hours per day. The average income of the entire sample fishermans wife is $\mathrm{Rp}$ 635.000 , - while the average income of the husband is Rp 1.000.000. Time allocation housework and childcare average on a fishermans wife is 5.5 hours (in the range of 16 hours per day), while the fisherman husband was no time available to it. The results of the qualitative analysis of gender relation show that the fishermen's wife had an egalitarian relationship, meaning the wife and husband has a role equal and balanced that allows them respect each other and work together. The wife was also found to have the flexibility in managing their shared money, which is from husband's income as a fisherman and the wife's income from the shop, maids or clothes washer.
\end{abstract}

Keywords: Fishermen, Allocation of time, Income, Socio-economic and Gender relations

\section{INTRODUCTION}

According to Coontz (1992) it was since the rise of industrialization era in America, the division of labor in the household emerge. Men who were previously work side-by-side with woman and children in family-based agricultural production, were now considered temperamentally unsuited to be involved in raising children and do the housework. So, the wives should do all the housework and childcare, and the husbands would limit their family contributions to being a good provider by working ouside the house.

In Indonesia, the general division of labor within the family, until now, has always placed the husband as breadwinner in the family. If the wife works outside the house it is called the secondary earner. Based on these terms, the wife's income certainly lower than her husband as the main breadwinner.

In conditions of poverty, such as in the area of assessment, the wife should work outside the home in addition to their primary task of managing the household. There are at least three main reasons why the wives participate in work outside the home based on review of several studies. First, because the construction in society makes the management of family consumption is the duty of women. Family economic problems are a matter of personal secrets of husband and wife. Women's inability to keep a secret about their problems will put the woman as "not a good woman," so that the wife often copes by deciding to work outside the house (Leli Ruspita, 2012). Second, according to Darmawan Triwibowo (2012) women are more vulnerable to poverty. Women's vulnerabilities to poverty are problems that found in developed and developing countries. 
Poverty also has a more severe impact on women and children because of their status as wives or daughters who depend on men as the main breadwinners. Third, according to Titik Hartini (2012) the involvement of women to go to work outside the house is because women have a high commitment to pay attention and take care of children and their families. She also tends to give all of her life for children and their families. So, if poverty happens, the wives got up and choose to work outside the house, then not a few of them who later have a larger income than her husband.

One of the theoretical perspectives in the process of domestic labor is the relative allocation of a resource. This perspective argues that the allocation of housework reflects power relations between men and women. Women are primarily responsible for housework, because they are economically depended upon their husbands and hence cannot successfully bargain out of doing domestic work (Brines, 1994 and Greenstein, 1996).

By opting to work outside the house, wives of fishermen will have a double burden. The first burden is to keep doing the household work, and the second is to work outside the house. In addition to the double burden, a result of working outside the house, is the change in gender relations.

According to Eichler (1981), dependency relationship of husband and wife can be either dominant or equivalent. If the husband or wife is totally dependent on her partner, it is called a dominant relationship, whereas when the husband and wife are interdependent or mutually dependent, this relationship is called equivalent. However, this relationship can be changed, if women work outside the house and earn money (Rosaldo, 1974). This is because the economic contribution to the household made by working women will cause them to gain "power" at the household. But in reality, according to Blood and Wolfe (1960), economic contributions generated by women working outside the home does not always lead to the rising power of women in the family.This is because it still depends on the position of family and the culture in the community.

Accordingly, this study wanted to look at time allocation, income and gender relations within the household of fishermen who have employed wives in Bedagai Serdang, North Sumatra, Indonesia. There are some issues that this study wants to analyze, first, to analyze the income and time allocation of fishermen wife compared with their husband. Second, analyze the allocation of time for housework and childcare of fisherman wives compare with their husband. Third, analyzing gender relations (decisionmaking and access control) between husband and wife in their household.

\section{METHODOLOGY}

In accordance with the topic of the study, which is to analyze gender relations within the poverty area, the location picked is the coastal area. In Indonesia almost all the coastal area where the fishermen and their wives lived are the poor areas, and poverty often forced the wives go to work outside the house. Specifically, the study area is in Serdang Bedagai, District of Tanjung Beringin. This is because this area is a district with the largest number of fishermen and their local income primarily from fish captured. Based on data from BPS also note that the income among the people in this district is low and categorized as of poor people in Indonesia.

This study is a survey with mixed method combining qualitative and quantitative. Quantitative assessment survey done through interviews based on the questionnaire. The questionnaire for the quantitative study consists of three parts. The first part is the socio demographic of respondents, especially regarding the workplace of wife. The second part is the allocation of productive time wives and husbands and their income per month. The allocation of productive time is calculated per day. Productive hours per day, adjusted to the custom within the study areas. For the husband who is a fisherman, the number of hours at sea converted into working hours per day. The third part is about the allocation of time for husband and wife to domestic work, especially for housework and parenting. Qualitative study is done through indepth interviews with respondents who have been chosen based on the results of a quantitative survey. 
Population studies are wives of fishermen who work outside the house within the area of study. Quantitative study used 30 fisherman's wife who is employed. The sample selection is done through snow ball sampling because there is no information about the job of fisherman's wife at the district office. The number of samples for qualitative assessment is five informants who have incomes greater or smaller than their husband.

Analysis and data processing are divided between two, the study for descriptive and qualitative study. Quantitative data analysis and processing used the descriptive statistical methods to determine the overall allocation of productive time a husband and wife, the allocation of time for domestic work of husband and wife, and the husband and wife's income. In the qualitative part, the result of in-depth interviews presented and discussed, in order to find the conclusion from the result of the analysis.

\section{RESULT AND DISCUSSION}

\section{Study \\ A. Result and Discussion of Quantitative}

Based on the results of a quantitative study of the 30 respondents who are wives of fishermen who work outside the house, it is found that their aged between 28 to 52 years. Their educations are from elementary to high school. They also have one to five peoples as their dependent. They have been worked outside the house of 1 to 15 years. There are five respondents working in the stalls, 14 respondents laundry workers, one respondent help selling rice cake for breakfast, eight respondents are maids, and two of the respondents work in the coffee shop. The results of descriptive quantitative analysis of the average total productive time husband and wife as well as the average income is presented in Table 1.
TABLE 1.

Productive time allocation and income of wife and husband

\begin{tabular}{|c|c|c|c|c|}
\hline \multirow[t]{2}{*}{$\begin{array}{l}\text { Job of The } \\
\text { Wife }\end{array}$} & \multicolumn{2}{|c|}{$\begin{array}{l}\text { Average } \\
\text { Productive } \\
\text { Time } \\
\text { (Hour) } \mathbf{1 6} \\
\text { Hours per } \\
\text { Day) }\end{array}$} & \multicolumn{2}{|c|}{$\begin{array}{l}\text { Average Income } \\
\text { (Rupiah/month) }\end{array}$} \\
\hline & Wife & $\begin{array}{l}\text { Hus } \\
\text { ban } \\
\text { d }\end{array}$ & Wife & Husband \\
\hline $\begin{array}{l}\text { Work in the } \\
\text { stalls }\end{array}$ & 3.6 & 4.1 & $\begin{array}{l}1,052,2 \\
65\end{array}$ & 814,500 \\
\hline $\begin{array}{l}\text { Laundry } \\
\text { workers }\end{array}$ & 9.8 & 4.3 & $\begin{array}{l}314,28 \\
5\end{array}$ & $\begin{array}{l}1,003,21 \\
4\end{array}$ \\
\hline $\begin{array}{l}\text { Helping } \\
\text { selling rice } \\
\text { cake } \\
\text { breakfast }\end{array}$ & 8.3 & 5.3 & $\begin{array}{l}450,00 \\
0\end{array}$ & 800,000 \\
\hline Housemaids & 10.3 & 4.1 & $\begin{array}{l}714,28 \\
5\end{array}$ & $\begin{array}{l}1,394,28 \\
5\end{array}$ \\
\hline $\begin{array}{l}\text { Work in the } \\
\text { coffe shop }\end{array}$ & 15.3 & 4.8 & $\begin{array}{l}1,986,1 \\
27\end{array}$ & 680,000 \\
\hline Average & 1.4 & 4.5 & $\begin{array}{l}634,45 \\
3 \\
\end{array}$ & $\begin{array}{l}1,001,25 \\
0\end{array}$ \\
\hline
\end{tabular}

According to Table 1., it appears that the highest total productive time is the wife who works in the coffee shop, and the lowest is helping selling rice cake for breakfast. This is because working in a coffee shop making workers must continue to be in the tavern until it is closed, whereas for helping selling rice cake requires the presence in the morning only. Conceivably fatigue faced by the wives who work in the coffee shop, which leaves only 0.7 hours for the purposes of her self, if it is assumed productive time starts at 6 $\mathrm{AM}$ and ends at $10 \mathrm{PM}$, according to habits of local communities.

When the comparison is made between the average productive time of husband and wife (Table 1), it can be seen that the average productive time of the wife is 11 hours per day at the time range 16 hours a day (from at 6:00 AM to 22:00 PM) while the husband is five hours per day. With productive time on average more than doubled compared to the husband, the average income of the entire sample fishermen wife is only $\mathrm{Rp} 635,000$, - while the average income of the 
husband is $\mathrm{Rp} 1.000 .000$, -. This shows that the higher the productive time is not followed by the higher incomes. Sharpe, Arsenault and Harrison (2008) and Field's (2011) described it as a reality in developing countries, especially in poor regions and often occurs to women due to discrimination against women workers. However, the majority of women's productive time is spent working inside the house which is not paid (free). Further, it is also can be seen from the table that the income of wife who works in the stall and in the coffee shop, is higher than their husbands.

Furthermore, the allocation of time for housework and parenting for husband and wife shown in Table 2.

TABLE 2.

Time allocation for housework and parenting of wife and husband

\begin{tabular}{|c|c|c|}
\hline \multirow{2}{*}{ Job of The Wife } & \multicolumn{2}{|c|}{$\begin{array}{c}\text { Average Time } \\
\text { for Housework and } \\
\text { Parenting (Hour) (16 } \\
\text { hours per day) }\end{array}$} \\
\cline { 2 - 3 } & Wife & $\begin{array}{c}\text { Hu } \\
\text { sband }\end{array}$ \\
\hline Work in the stall & 6.95 & 0 \\
Laundry workers & 5.5 & 0 \\
Helping selling rice & 3.25 & 0 \\
cake for breakfast & 4.88 & 0 \\
Housemaids & 7.75 & 0 \\
Worker in the coffe & 5.65 & 0 \\
\hline shop & & \\
\hline Average &
\end{tabular}

It can be seen on Table 2 that the highest allocation of time doing housework is the wife who works in the coffee shop. This is because every day they opened at noon and close at $10 \mathrm{pm}$. The housework that is not all done completely since the morning will continue to be processed on the sidelines of working hours in the coffee shop. Conversely, the lowest time allocation for domestic work is the fisherman's wife who is a maid to sell rice cake as breakfast. She has paid hours of work only from six to $10 \mathrm{am}$. After $10 \mathrm{am}$, she will do the domestic work, but at one o'clock in the afternoon, she had to return to helping business owners prepare rice cake to sell tomorrow. If calculated on average, the time takes of the wives to do domestic work is 5.5 hours (in the range of 16 hours per day). This average amount of time to do domestic work is still higher than their husband. The husband does not want to dedicate any of his time to do housework, Thus it can be stated that, even though the wife had to help her husband to overcome financial problems by working outside the home, but the husband did not intend to help the wife doing the domestic work. This result is not surprising, given the husband's comments about the housework, that the houseworks are women responsibility, and they feel no need to participate in the affairs of women. This result is very different from the result of the study that has been done in developed countries, such as assessment of Ross (1987), which found that in the US, husband's relative contribution in the house works increase when the wife is employed, although the kind of husband must strictly be well-educated and less traditional sex-role.

It is commonly known that the wives tend to feel extremely responsible and concerned with housework. Women are not willing to work outside the house or leave work outside the house if no one is doing the domestic work. Moreover, husband will tend to forbid his wife to work outside the house because no one does the housework. This opinion is in compliance with the results of the study Blair and Lichter (1991) on the American family which conclude that female employment is positively related to men's absolute and proportionate contribution to housework. Thus, a husband who approved his wife work outside the home should take over or at least help the wife in her domestic work.

The division of labor in the household is very determined by the husband. The result of study from Ross (1987) shows that the division of labor in the household is significantly dependent on the husband's values and the relative power of husband and wife, not conditional on wife education and attitudes. So, although education and a wife's attitude are pretty good, does not mean that these households will have a system that equal division of labor between husband and wife, because the husband who determines the division of labor. Only husband who welleducated, less-traditional sex roles have more 
egalitarian gender relations are willing to do domestic work replacing his wife.

Another factor that is expected to lead to the growing contribution of husbands in household work is if the gap between the husband and wife's earnings is small. Washbrook (2007) study in the UK also found that in households with children, greater equality of wages between husbands and wives is associated with an Increase in female market work and a reduction in female domestic work, but they find no evidence that men's time is divided more equally between the two sectors when wage rates are more equal. This implies that reductions in gender specialization come about largely because wife's earnings are used to purchase substitutes for wife's domestic production, rather than because husbands assume greater responsibility for domestic work. Furthermore, culture is also expected to affect this. Study of Wight, Bianchi and Hunt (2013) found that in America, partnered White men appear to spend more time on average in housework than partnered Black men, while Hispanic men, on the other hand, do less housework than White men but not necessarily less than other minority men. Asian men's time spent doing housework is low relative to the other groups.

The unwillingness of the husband to engage in domestic work, will make the work very difficult for women who are in poverty and had to go to work outside the house. These women will constantly be working on, and she will be going to feel very tired, lonely and tend to be depressed. This of course will affect parenting. Thus gender relations need to become an integral part of all poverty reduction strategies. In the next section, there will be a qualitative discussion of how gender relations (decision-making, access and control) occur in families of respondents.

\section{B. Result and Discussion of Qualitative Study}

Of the five cases of working wives shows that women have been working more than 10 hours per day than her husband. This shows the phenomenon of working mothers with multiple roles suffer from the excessive burden, corroborated by the evidence of women do not remain silent facing problems in meeting their daily needs.
"At first we settled in Pekan Baru in the village of my husband (Bapak). But life there is not promising, it's difficult to find money to buy food. Finally, I invite my husband (Bapak) to have moved here to my hometown. Thankfully my husband (Bapak) wants to move here."

The work performed by fisherman's wife is to open a small stall, in addition to be a domestic and laundry workers. Although women have to spend half her time to take care of the household and the family, it turns out that they also have to work more to meet everyday needs within the household and family.

"Because the money from my husband is not enough, I think hard and finally convince myself to open a shop with little funds. At least, I'm not just relied on my husband. "

\section{Decision Making}

In working both in domestic and outside, fisherman's wife has an important role in decision making. This is shown by several examples of cases experienced by Ibu Ina (a pseudonym) of the following:

"Indeed, any income derived from fishing my husband (Bapak) has always given to me. I'm the one who manages all income and expenditure in the household, including in handling this stall. Bapak is a person that has not much of request and not too concerned with domestic matters, including the management of this stall. Even the food to eat, he does not have any requests. He believes that there isn't any problem, as long as there is food to eat."

"At first, Bapak can't sail and fishing but over time, he could be a fisherman. However, this job is unreliable because it relies on the weather and the amount that can be caught. It is already one month's Bapak did not go fishing because the weather is uncertain".

From the description of the case experienced by Yani (pseudonym) shows that women have a series of great responsibility, from domestic work to the activities of informal employment with large workloads. This shows that the responsibility of men to household activities seem to increasingly decline while women work more widespread. 
Regardless of the power of the wife still has the

\section{Access and Control}

"I (Ibu) used to open a coffee shop because a lot of people go fishing on the sea, they come into the coffee shop since the dawn, they drink, smoking the cigarettes and eat fried foods. The condition is crowded. Currently, few fishermen go fishing. So, I decided to close the shop. My works at this moment in time ... ya... preparing the ice for Bapak to sell."

Although no longer open the stalls, the wife still working to help her husband, by making a puncture ice from bamboo and preparing the merchandise. The husband task is to sell the ice within village area. Now her husband practically rarely goes to sea because the weather is bad. The income from sales and fishing entirely to be used to meet domestic needs everyday. Setting, decision-making and the management of money left on the hands of the wife.

Domestic affairs, such as the management of the household as well as the provision of health needs and hospital treatment mostly decided by the mother.

"If I cook, well ... anything, for Bapak it was never a problem, if we have to eat the rice with salt only, it is still alright for Bapak. Whatever I cook will be eaten by Bapak."

\section{Final Analysis}

\section{- Gender Relations}

Although the mother fully engaged in housework and childcare, but in terms of the relationship of husband and wife, the wife has an egalitarian relationship with her husband, meaning they have a role equal and balanced that allows them respect each other and work together.

\section{- Decision Making}

In decision making, primarily for domestic affairs, the wife has the power to decide almost everything. Examples for daily food, for school children, for treatment.

\section{- Access and Control}

Wife had the financial flexibility to manage shared, both of the husband's income as a fisherman, nor the wife's income from the shop, maids and laborers wash. burden of excessive (multiple burden). From the income side, it is a large part of the extra income, but in some cases, the wife's income is greater than the husband's income. Nevertheless, these wives have gender relations can be categorized egalitarian.

\section{CONCLUSION}

The total productive time of the wives works are 11 hours per day, while the husband is five hours per day. The average income of the entire sample fisherman's wife is Rp 635.000- while the average income of the husband is Rp 1.000.000. However, time allocation for housework and childcare average on a fishermen's wife is 5.5 hours (in the range of 16 hours per day), while the fisherman husband was no time available to it. The results of the qualitative analysis of gender relations show the fishermen wife has an egalitarian relationship with her husband, meaning they have an equal role and balanced that allow them respect each other and work together.

\section{REFERENCES}

Blair, S. L., \& Lichter, D. T. (1991). Measuring the division of household labor gender segregation of housework among American couples. Journal of family issues, 12(1), 91113.

Blood, R. O., and Wolfe, D. M. (1960). Husbands and wives: The dynamics of married Living. Glencoe, IL: Free Press.

Brines, J. (1994). Economic dependency, gender, and the division of labor at home. American Journal of Sociology, 100(3), 652-688. Retrieved from http://www.jstor.org/stable/2782401

Coontz, S. (1992). The way we never were: American families and the nostalgia trap. New York: Basic Books.

Darmawan Triwibowo. (2012). Kerentanan perempuan terhadap kemiskinan: Temuan empiris dan tantangan pengarusutamaan gender. Jurnal Perempuan, 17(3), 83-97. 
Eichler, M. (1981). Power, dependency, love and the sexual division of labour: A critique of the decision-making approach to family power and an alternative approach. Women's Studies International Quarterly, 4(2), 201-219.

Fields, G. S. (2011). Poverty and low earnings in the developing world [Electronic version]. Retrieved [12/12/2016], from Cornell University, ILR School site: http://digitalcommons.ilr.cornell.edu/worki ngpapers $/ 152$

Greenstein, T.N. (1996). Husbands' participation in domestic labor: Interactive effects of wives' and husbands' gender ideologies. Journal of Marriage and Family, 58(3), 585595. doi:10.2307/353719

Leli Ruspita. (2012). Keterasingan perempuan dari pekerjaannya: Kemitraan suami-istri dalam pengelolaan keuangan rumah tangga. Jurnal Perempuan, 17(3), 23-45.

Rosaldo, M.Z. (1974). Woman, culture, and society: A theoretical overview. In Rosaldo, M. Z., Lamphere, L., \& Bamberger, J. (Ed). Woman, culture, and society. California: Stanford University Press.

Ross, C. E. (1987). The division of labor at home. Social forces, 65(3), 816-833.

Sharpe, A., Arsenault, J. F., \& Harrison, P. (2008). The relationship between labour productivity and real wage growth in Canada and OECD countries. Ottawa, Ontario: Centre for the Study of Living Standards.

Titik Hartini. (2012). Pemberdayaan ekonomi perempuan: Keluar dari kemiskinan. Jurnal Perempuan, 17(3), 65-81.

Washbrook, E. (2007). Explaining the Gender Division of Labour: the role of the gender wage gap. CMPO Working Paper Series No. 07/174: 1-88. Electronic version: http://www.bris.ac.uk/Depts/CMPO/worki ngpapers/wp174.pdf

Wight, V. R., Bianchi, S. M., \& Hunt, B. R. (2013). Explaining racial/ethnic variation in partnered women's and men's housework: Does one size fit all? Journal of family issues, 34 (3), 394-427. 